\title{
THE DEATH OF THE AUTHOR | THE DEATH OF THE ARCHITECT? MEANING IN ARCHITECTURE AND THE ROLE OF USERS
}

Julian Franke

Technical University of Berlin franke-julian@t-online.de

\section{A B S T R A C T}

In his work The Death of the Author (1967), Roland Barthes creates a new definition of authorship, in that the author is not the real originator of meaning in literature, but rather the reader. This questions the influence and responsibility of originators in creative fields in general. This paper applies Barthes's thesis to the profession of architecture. Therefore the role of users is discussed, as well as meaning and language in architecture. With the help of the semiotic work by Umberto Eco and texts by Roman Ingarden and Jonathan Hill, the paper will attempt to show how the sole image of the architect is challenged, but also what makes him/her still recognisable and responsible.
KEY WORDS

ROLAND BARTHES

DEATH OF THE AUTHOR

UMBERTO ECO

SEMIOTICS

MEANING AND LANGUAGE OF ARCHITECTURE 


\section{INTRODUCTION}

In architecture the sensual and cognitive are mainly bound together through the sense of vision and semiotic processes. Because of this, it is necessary to look into meaning and language in architecture and how how the built environment can be read and interpreted. A user's individual behaviour and interpretations of buildings and architectural elements show that there is not a single meaning that brings into question authorship of the architect. In his work The Death of the Author (1967), Barthes creates a new definition of authorship. In it, he argues that the reader is the real creator of meaning in literature instead of the author. For this reason, it is pertinent to ask if his text and assertion can also be applied to other creative fields.

This essay draws comparisons between the main issues of Barthes's work and architecture. In this way, the essay examines what the role of users can be, how some architects can still be recognised by their work, and the question of responsibility. The arguments are based on works by Umberto Eco, Roman Ingarden and Jonathan Hill.

\section{THE DEATH OF THE AUTHOR}

In The Death of the Author, Barthes wants to highlight that the author of a text is not the real originator of meaning, that he/she is not fully responsible for the content, and that the 'genius' of the author cannot be found in the text. The author acts more as a mediator who is "[...] borne by a pure gesture of inscription [...]" His work has "[...] no other origin than language itself, language which ceaselessly calls into question all origins." In this way Barthes - much like Maurice Merleau-Ponty - borrowed the basic ideas of Ferdinand de Saussure's definition of language as a structuralistic system of differential elements in which each word and term requires another term or reference to define its meaning. For Barthes, language and thus the text is " $[\ldots]$ a tissue of quotations drawn from the innumerable centres of culture."3

Last but not least, Barthes concludes the author can only mix writings, ${ }^{4}$ he is weak and limited in his creativity. Meaning is always a result of the context and the individual understanding of the reader, who turns out to be the most important part, as he/she is the "[...] place where this multiplicity is focused $[\ldots]^{\prime \prime 5}$ 
The idea that the author is not a true originator, but a person influenced by a complex referential system, where the initial recipient becomes more important than the creator of the work, is of vast importance to acts of creation in general. Barthes does not say that the author is completely powerless (or 'dead'). The author still holds an influence over the reader, of course, but he argues mainly about meaning in literature and that the reader is more important in developing this meaning. As the topic of meaning is so important, it is thus important to ask what meaning truly is in other acts of creation.

In literature there is a relationship between the writer and the reader, just like other relationships exist, such as that of a painter and viewer of the painting, a musician and an audience or for the sake of this paper, the architect and the user. In each relationship, it would be important to define how meaning is defined, who creates it and if it is comparable with Barthes's definition. Thus, questions arise about the physical existence of the creations, materiality, signs and semiotics, subjectivity and objectivity, and the necessity for recipients. This paper intends to discuss new perspectives of Barthes's work, acts of creation and different ways in which meaning can be created and transmitted.

\section{THE INFLUENCED ARCHITECT}

To discuss if the architect is the real originator of his/her work or more of a mediator who is mixing already known ideas or conventions of the innumerable centres of culture, we first need to have a look at the typical ways and many factors that are important in the work of architects.

Jonathan Hill, an English architect and architectural historian who argues that users have a major importance in architecture, says that "[...] the idea of sole authorship is important to architects because of the long-held, often false, assumption that art is the product of individual creativity." Against the common image of the one and only architect, who brings everything to life in a project, he is in fact only one of many people in the process of creating a building. There are usually many persons working on a project in a group, as the workload is extensive and complex for a single architect. The client has his own ideas of his building that the architect must consider as well. Regulations and laws also greatly influence the architect's work, as they have the statutory power to cancel whole plans or reduce ideas to a minimum. But there are many more examples that are less common, which are presented in the following part. 
Architecture is materialistic and has a physical existence and a direct relationship with the environment, ${ }^{7}$ people, urban design, complex social systems and cultures. Umberto Eco even says, "[...] the architect, in practice, is continually obliged to be something other than an architect. Time and again he is forced to become something of a sociologist, a psychologist, an anthropologist, a semiotician ..." ${ }^{\text {"8 }}$ All these are subjects and determining influences that make demands and force the architect to adjust his/her ideas.

More influences that concern the fact of the physical existence are for example the scale of space in relation to the human body. The architect plans buildings for other humans, has their (typical) sizes in mind and uses often regulated and common elements such as typical door sizes, heights of balustrades, furniture, stairs, and so on (more about this in the chapter The Role of Users). Also phenomenological reasons such as the influence of typical room sizes, arrangements, or colours on the user can determine the architect's choices. One can say that these examples show especially that the architect seems to be free in choosing materials, atmospheres to create or social relations to influence. But in most cases architect's work is noticeably conservative and follows the mentioned conventions. This is also related to the fact that architecture is concerned primarily with function and thus has to meet regulations and the user's needs.

While all these factors illustrate that the architect is not truly free and that he/ she must deal with several external factors, the following sections will explore further the aspect of meaning in architecture and show if or how the architect, despite all these external influences, can still be a creative originator.

\section{MEANING AND LANGUAGE OF ARCHITECTURE}

In order to compare literature and architecture it is essential to compare their relationship to language and elemental meaning. While it is obvious that literature deals with language, the meaning of words and written signs that can be read, it seems quite unusual to talk about language and the act of reading in architecture. However, it becomes clear relatively quickly how common and important language and meaning are to architecture as well. ${ }^{9}$ There is no person talking, no written word telling us something, rather the building itself seems to 'speak' to us.

To begin with, it is obvious that there are some buildings that seem to express more meaning than others. Buildings that can be defined directly by their 
properties and look like, for example, a Gothic church, while others look like a neutral box, which have no clear definition. ${ }^{10}$ It can be said that if there is a language of architecture, it is more a secondary feature, while a book - or better said a story in literature - could not even exist without language and meaning. With a focus on semiotics and the work of Umberto Eco, I will now turn attention to how meaning can be defined in architecture.

"If semiotics, beyond being the science of recognised systems of signs, is really to be a science studying all cultural phenomena as if they were systems of signs [...] - then one of the fields in which it will undoubtedly find itself most challenged is that of architecture."'11

With this quote, Umberto Eco introduces his work on semiotics in architecture, in that he mainly shows how architecture can be read and how denoted (denotations) and connoted (connotations) functions are elements of a language in architecture, through which it can be experienced as communication. ${ }^{12}$

Closer inspection reveals that even the simplest functions are communicated by typical shapes, sizes, positions in a building, and so on, so " [...] the form of the object must, besides making the function possible, denote that function clearly enough to make it practicable as well as desirable [...]"13 A staircase must have a typical size and shape that one recognises as such and that a human can walk on it.

Beside this, there seem to be another communicating sphere through which it is even possible to express social, political or cultural messages as a whole with architectural elements. This second connoting and symbolic function ${ }^{14}$ of architecture is, for example, recognisable in when we compare a simple wooden staircase to a big baroque one with golden balustrades. Both have the first denoting function of an element that connects different levels, but the big baroque one represents a sense of importance and power, symbolising the might of the building or its owner.

Roman Ingarden makes the difference between the simple and not yet communicating basis of existence (Seinsfundament), for example stones, and an additional communication or symbolic function of the real building (reales Gebäude) or opus of architecture (Werk der Architektur). ${ }^{15}$ From his point of view, architecture can change its meaning if the symbolic understanding changes, even if the basis does not change. Meaning seems to be an external matter, brought by recipients and influenced by the environment or the context 
that it is built in, in correspondence with architectural properties that can be read, interpreted and manifested as conventional $\operatorname{codes}^{16}$, that can also change through generations or cultural progress. Just like in literature each word and term requires another term or reference to define its meaning, in architecture "[...] every code contains formative elements whose meaningfulness is ambiguous without indexical correlation to sign formations in other codes." 17

Ingarden's definition of meaning in architecture comes close to that in literature that Barthes talks about. A book with its imprinted pages can be understood as the materialistic basis that does not change - and could even have no meaning if the letters and words were not arranged in a way that can be understood - but have different meanings to each reader and can change over time and through cultural progress.

A good example of this in architecture is illustrated by Barthes himself who talks about the Eiffel Tower in Paris and its transition from a disliked building that was seen as being useless to a loved symbol of the city and the country. Throughout this period, the materialistic basis never changed, merely public opinion. ${ }^{18}$

The idea of changing meanings of a building and the dependence on codes reveal again a weakness and possible death of the architect, as

"if the codes operative in architecture allow only slight differences from a standardised message, however appealing, then architecture is not the field of creative freedom some have imagined it to be, but a system of rules for giving society what it expects [...], ${ }^{19}$ Eco says.

The next chapter focuses on the weakness of the architect by presenting the role of users.

\section{THE ROLE OF USERS}

In Barthes's The Death of the Author the role of the reader is one of the most important aspects, which is why it is inevitable to have a look at the role of users in architecture.

Hill again says that "just as the reader makes a new book through reading, the user makes a new building through using. ${ }^{20}$ There can be physical changes, like moving walls to modify a floor plan and changing room structures or shifting materials and colours. 
"The user is an important consideration in the architect's design process. But the user is also a threat to the architect because the user's actions may undermine the architect's claim to be the sole author of architecture."21

The way the user understands and uses the building can in itself change its meaning and reduce the architect's power. Apart from the mentioned influences, there are deeper questions of the role of the user if we consider the role of the reader as absolutely necessary in bringing a body of work to life. Literature cannot exist without the reader; it must be read and the reader must bring meaning to it. Is this the case for the user in architecture?

The user is always an inherent part of the process of designing and building as he/she is always included in the architect's ideas and intentions. However, a big difference between architecture and literature is simply illustrated in how each work comes to life. The reader has to know how to read and must be aware of human language that he/she can be influenced by literature. Architecture, with its objectivity, can even influence beings that are not aware of the human language. The language of architecture with its functions can even communicate without language as it appeals to the needs of living beings. The meaning of a shelter as an accommodating and protective space, such as caves, can even be understood and used by primitive creatures without human language. In this sense, the role of the user is not as predominant as in literature. Only if the functions are not denoting or connoting in the right way, human language becomes important to explain what the architectural language does not.

As it becomes clearer that the user can also be powerless, somehow determined or guided by the architect's ideas and design, it looks like the architect can still have more power than it appeared so far. This leads us to the last chapter which deals with how distinctive design is possible and how architects can be recognized by their work.

\section{DISTINCTIVE DESIGN}

The term Distinctive Design can be used in two different ways: On one hand, it relates to the way the architect can be recognized through his/her distinctive and characteristic design so that there can be elements and a kind of individual style which reminds us of a particular architect and could potentially save him/her from his/her 'death'. On the other hand, it relates to the way the architect can determine the user's behaviour or feelings with his distinctive work. 
If we question architectural authorship then how is it possible that many famous architects are recognized by their work? Some examples include the extraordinary structures by Frank Ghery and Zaha Hadid or plain and functionorientated works by architects of the Bauhaus school. Can we argue with this topic of style against The Death of the Architect?

At this point the word 'mixing' by Barthes is important to consider and might be the weak point of his arguments. While the word mixing suggests something like a random use of elements, the architect's individual way of 'mixing' better called composing - is what defines his/her style.

The architect's style can be seen as an individual code that is in general a composition of other codes and its repetitive use. The repetitive perception of these elements and the correlation between them and the architect as a person works in a symbolic way. As symbols are the result of progress in time, cultural developments, or intersubjective understandings, it is not the power of the architect to make himself recognizable, but the power of users and recipients to find the comparisons and create these symbols.

An important fact is that not every recipient or user of a building can make these correlations. Experiences with different buildings and studies of architectural work are necessary. This reinforces the idea that there is a connection between the user and his knowledge, but it is still important to discuss the role of the architect as the author, especially by addressing the topic of responsibility.

\section{RESPONSIBI LITY}

As the user gives meaning to architectural elements one can deny the architect's responsibility. The same applies to the author in literature. However, in both cases it would be neglectful not to consider the determining role of 'mixing' in the creation process as it is a conscious act. As the architect is able to predict the user's interpretations and expectations he/she has a considerable degree of responsibility.

The architect can almost articulate meaning by using elements, materials, forms, etc. that are very likely to be interpreted by the user in a specific way and to be given meanings that can be the same as the ones that the architect intended. Architects that are able to affect later interpretations of the users can most likely avoid their 'death'. 
The relation between the architect and the user especially makes it possible for the architect to play with elements, somehow design riddles, things that are especially made to confuse or be poetical. His individual way of composing things in relation to his ability to expect how users will interpret his/her work makes him/her a powerful actor and an individual creator. The same considerations on individual interpretations can be applied to the author-reader relationship in literature, providing a critique of Barthes's thesis.

The architect and author is not only responsible for those things that he/she has predicted, but also for that which he/she should have predicted, but failed to do so. If misinterpretations by users guide them into dangerous situations because the design was denoting or connoting a certain first or second function different to that intended, then the architect cannot blame the user for his wrong understanding as he/she had to predict all possible interpretations. Only the fact that a work was meant differently does not free an originator from being responsible.

\section{CONCLUSION}

Different examples of architect's work, language and meaning in architecture and the role of the user have shown that Barthes's The Death of the Author is applicable to architecture as well. Even if a creator doesn't fully cease to exist and has the power to choose certain elements which will generate specific reactions from the user, he/she will still be in the dilemma of using already known ideas and conventions based on prior experiences and related to the innumerable centres of culture. Along with being influenced by other parties in design processes, the architect depends on users and their individual interpretations and behaviour.

The language and meaning of architecture that is based on semiotic systems and codes that have evolved through countless cultural, social, etc. progresses make it clear that in architecture a single ultimate ,secret' or meaning is not entirely possible, similarly to what Barthes argues is the case in literature. Although, if a single architect can be recognised by their work this symbolic relation is still a result of recipient's observations and interpretations. The architect can't be the sole originator of a work, but he still carries responsibility. What Barthes calls 'mixing texts' - in architecture means 'mixing architectural elements' - should better be called 'composing elements' as it is a conscious action. The architect displays an awareness of users' eventual interpretations when choosing which elements to include and exclude in his/her work. 
In that sense the architect is not truly dead and holds the power to anticipate which meaning users will bring into his/her work. This is also applicable to authors in literature, that is why Barthes's statement should be relativized by questioning the term 'mixing' and seeing it more as a conscious and powerful action that makes creators recognisable, responsible and 'alive'.

Roland Barthes, “The Death of The Author," in Image - Music - Text, Roland Barthes (New York: 1977), 146.

Ibid.

"His only power is to mix writings, to counter the ones with the others, in such a way as never to rest on any one of them," ibid.

"The architectonic code is a system of relationships manifested in material formations, and the medium of a given code is normally a mosaic of shapes, relative sizes, colors, textures, and materials - in other words, anything drawn from the entire set of material resources potentially offered by the planetary biosphere, including our own and other bodies." Preziosi, Donald. "Architecture, Language, and Meaning. The Origins of the Built World and its Semiotic Organization," in Approaches to Semiotics 49, eds. Thomas A. Sebeok, Roland Posner, and Alain Rey (The Hague: 1979), 4 
Umberto Eco, "Function and Sign: The Semiotics of Architecture," in Rethinking Architecture: A Reader in Cultural Theory, ed. Leach Neil (London: 1997), 190.

Barthes talks about Urban Design and the way to read a city: “And here we rediscover Victor Hugo's old intuition: the city is a writing. He who moves about the city, e.g. the user of the city (what we all are), is a kind of reader who, following his obligations and his movements, appropriates fragments of the utterance in order to actualize them in secret." Roland Barthes, "Semiology and the Urban," in Rethinking Architecture: A Reader in Cultural Theory, ed. Nil Leach (London: 1997), 163.

cf. R. Ingarden: „Es könnte zwar im Prinzip jedes Gebäude, und sogar jede in der Natur sich befindende und durch die Tätigkeit des Menschen umgeänderte Gegenständlichkeit, zur „Kirche“ eingeweiht werden. Aber die Eigentümlichkeiten des betreffenden religiösen Kultus sowie die daraus sich ergebenden praktischen Bedürfnisse führen dazu, daß man bestimmte Forderungen an das stellt, was z.B. zur „Kirche“ gemacht werden soll. Es bildet sich eine gewisse Tradition...“ Roman Ingarden, "Das Werk der Architektur," in Untersuchungen zur Ontologie der Kunst, Roman Ingarden (Tübingen: 1962), $263 \mathrm{f}$.

Umberto Eco, "Function and Sign: The Semiotics of Architecture," in Rethinking Architecture: A Reader in Cultural Theory, ed. Leach Neil (London: 1997), $173 \mathrm{f}$.

Ibid., 174.

Roman Ingarden, "Das Werk der Architektur," in Untersuchungen zur Ontologie der Kunst, Roman Ingarden (Tübingen: 1962), 264.

"The architectonic code is a system of relationships manifested in material formations, and the medium of a given code is normally a mosaic of shapes, relative sizes, colors, textures, and materials - in other words, anything drawn from the entire set of material resources potentially offered by the planetary biosphere, including our own and other bodies." Donald Preziosi, "Architecture, Language, and Meaning. The Origins of the Built World and its Semiotic Organization," in Approaches to Semiotics 49, eds. Thomas A. Sebeok, Roland Posner, and Alain Rey (The Hague: 1979), 4.

Ibid., 1.

Roland Barthes, "Semiology and the Urban", 166.

Umberto Eco, "Function and Sign: The Semiotics of Architecture", 186

Jonathan Hill, Actions of Architecture. Architects and Creative Users (London: 2003), 70.

Ibid., 2. 
Barthes, Roland. "Semiology and the Urban." In Rethinking Architecture: A Reader in Cultural Theory, edited by Neil Leach. London: 1997.

Roland Barthes. "The Death of The Author." In Image - Music - Text, by Roland Barthes. New York: 1977.

Eco, Umberto. "Function and Sign: The Semiotics of Architecture." In Rethinking Architecture: A Reader in Cultural Theory, edited by Neil Leach. London: 1997.

Hill, Jonathan. Actions of Architecture. Architects and Creative Users. London: 2003.

Ingarden, Roman. "Das Werk der Architektur." In Untersuchungen zur Ontologie der Kunst, by Roman Ingarden. Tübingen: 1962.

Leach, Neil (ed.). Rethinking Architecture: A Reader in Cultural Theory. London: 1997.

Preziosi, Donald. "Architecture, Language, and Meaning. The Origins of the Built World and its Semiotic Organization." in Approaches to Semiotics 49, edited by Thomas A. Sebeok, Roland Posner, and Alain Rey. The Hague: 1979. 